DOI: $10.15290 /$ bsl.2019.15.12

\author{
Małgorzata Sokołowicz \\ Instytut Romanistyki \\ Wydział Neofilologii \\ Uniwersytet Warszawski \\ e-mail: malgorzata.sokolowicz@uw.edu.pl \\ ORCID: 0000-0003-0554-8852
}

\title{
„Ach, jakże cudowne jest życie!" Tunezyjskie fascynacje Aline Réveillaud de Lens: przestrzeń
}

„Z Fezu dotarła do nas wiadomość o śmierci pani Réveillaud, z domu de Lens, która [...] publikowała bardzo cenione relacje z podróży i impresje o świecie muzułmańskim", pisano 2 marca 1925 roku w Les Annales coloniales ${ }^{1}$. Rzeczywiście, 10 lutego w Fezie, w wieku niespełna 44 lat, zmarła Aline Réveillaud de Lens, malarka, jedna z pierwszych kobiet przyjętych na Akademię Sztuk Pięknych w Paryżu, która wraz ze swoim mężem André Réveillaud, urzędnikiem kolonialnym, w 1911 roku wyjechała do Tunezji, a w 1913 do Maroka. Ze względu na słabe zdrowie z czasem coraz mniej malowała, a coraz więcej pisała. Jej książki, podpisywane tak jak i obrazy enigmatycznym "A.R. de Lens": Le Harem entr'ouvert [Uchylone [drzwi] haremu], Derrière les vieux murs en ruines [Za starymi zrujnowanymi murami] cieszyły się dużą popularnością wśród czytelników. Teoretycy powieści kolonialnej również cenili jej twórczość, chwaląc rzetelność, z jaką przedstawiała życie muzułmanek i ich sekrety ${ }^{2}$. W jej ostatniej książce, L'étrange aventure d'Aguida [Dziwna przygoda Aguidy], wydawca zapowiadał publikację dwóch kolejnych powieści oraz dziennika ${ }^{3}$. Śmierć pisarki położyła kres tym planom.

\footnotetext{
1 Nécrologie, „Les Annales coloniales”, 2/03/1925, nr 31, s. 2. Wszystkie tłumaczenia pochodzą od autorki artykułu.

2 Zob. m. in. R. Lebel, Histoire de la littérature coloniale en France, Paris 1931, s. 121.

3 Zob. A.R. de Lens, L'étrange aventure d'Aguida, Paris 1925. Dziennik miał zostać wydany pod tytułem Le Journal intime de A.R. de Lens [Dziennik A.R de Lens].
} 
Dziennik ukazał się drukiem dopiero w 2007 roku. W dziale rękopisów francuskiej Biblioteki Narodowej, w teczce braci Tharaud, odnalazł go Philippe Lejeune, który pracował akurat nad swoją książką Le moi des demoiselles: enquête sur le journal de jeune fille [Panieńskie ja: śledztwo w sprawie dzienników młodych dziewcząt] ${ }^{4}$. Potem zainteresowała się nim Martine Lévy, właścicielka wydawnictwa La Cause des Livres. To dzięki niej dziennik został w końcu opublikowany ${ }^{5}$. Ta publikacja posłuży nam za materiał do przedstawienia tunezyjskich fascynacji Aline Réveillaud de Lens.

Aline Réveillaud de Lens wyjechała do Tunezji zaraz po ślubie, 19 kwietnia 1911 roku. Zamążpójście miało z pewnością wpływ na postrzeganie przez nią nowego kraju. $Z$ jednej strony czuła się absolutnie szczęśliwa, z drugiej wiedziała, że jej związek nie był do końca akceptowany przez obie rodziny i chciała wyjechać, żeby móc się nim w pełni cieszyć. Mąż był od niej o sześć lat młodszy i przez pewien czas uzależniony od hazardu, jego rodzina była protestancka, rodzina de Lens - katolicka i, na domiar złego, para postanowiła nigdy nie konsumować małżeństwa. Zresztą artystka już od dawna odrzucała burżuazyjny świat Paryża i po prostu nie chciała dłużej żyć we Francji, ograniczana tamtejszymi konwenansami. Najpierw para planowała wyjechać na Tahiti. Potem okazało się, że prawdopodobnie trafią do Algierii. „Mnie jest wszystko jedno”, pisała Aline de Lens, „bylebyśmy tylko byli razem $\mathrm{w}$ jakimś pięknym, słonecznym kraju, daleko stąd, $\mathrm{z}$ dala od cywilizacji, od społeczeństwa, od nieba w kolorze sadzy" ${ }^{6}$. W końcu okazuje się, że André zostaje skierowany do Tunisu: „[Będę] żyć w blasku słońca, pośród radosnych kolorów i przezroczystych cieni, z dala od banalnego, światowego, zbyt ucywilizowanego życia we Francji...", cieszy się pamiętnikarka [s. 175]. „[André] zabiera mnie do kraju słońca, koloru i malowniczości", dodaje [s. 175].

Czy Tunezja opisywana w dalszych częściach pamiętnika okaże się rzeczywiście „krajem słońca, koloru i malowniczości”? W jaki sposób Aline de

\footnotetext{
4 Zob. Ph. Lejeune, Le moi des demoiselles : enquête sur le journal de jeune fille, Paris 1993, s. $84-85$.

5 We wstępie Martine Lévy wyjaśnia również, jak maszynopis pamiętnika trafił do braci Tharaud. Przekazał go im mąż Aline de Lens, licząc zapewne na pomoc w publikacji. André Réveillaud zginął jednak w wypadku samochodowym w 1926 roku, a bracia Tharaud posłużyli się obszernymi fragmentami dziennika, pisząc swoją powieść Les Bien aimées [Ukochane], którą opublikowali w 1931 roku. Oczywiście na publikacji samego dziennika w takiej sytuacji wcale im nie zależało. Zob. M. Lévy, Aline R. de Lens, une femme sublime, w : A.R. de Lens, Journal 1902-1924. "L'amour, je le supplie de m'épargner...", Paris 2007, s. 15-17.

6 A.R. de Lens, Journal 1902-1924. "L'amour, je le supplie de m'épargner...", s. 173. Wszystkie cytaty pochodzą z tego wydania, dalej będzie podawany jedynie numer strony w tekście głównym. Jeśli nie podano inaczej - tłumaczenie autorki artykułu.
} 
Lens relacjonuje pobyt $\mathrm{w}$ tym kraju? Na te pytania postaram się odpowiedzieć w niniejszym artykule, skupiając się przede wszystkim na opisach przestrzeni.

Definiując geokrytykę, Bernard Westphal pisał: „Chodzi o zbadanie przestrzeni [przedstawianych] poprzez tekst i w tekście [...] oraz relacji kul-

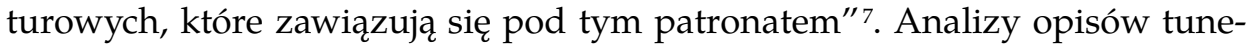
zyjskich przestrzeni zawartych w pamiętniku Aline de Lens przedstawię tu $\mathrm{z}$ tej właśnie perspektywy w trzech odsłonach. Najpierw skupię się opisach Tunezji jako przestrzeni światła i koloru, malarskiego raju. Następnie omówię przedstawienia przestrzeni uznawanych za symboliczne: oazy i pustyni. W ostatniej części skoncentruję się na ujęciu przez pamiętnikarkę miejsc, które z perspektywy dziewiętnastowiecznego orientalizmu postrzegane były bardzo stereotypowo: pałacu, haremu i hammamu, czyli tureckiej łaźni. Analizy te pozwolą zobaczyć, na ile fascynacja Tunezją - której oznaki widać w dzienniku jeszcze przed wyjazdem - wpływa na sposób przedstawienia tego kraju oraz jakie relacje kulturowe odzwierciedlają opisy tunezyjskich przestrzeni.

\section{Kraj światła, kraj koloru}

W Afryce Północnej to przede wszystkim światło urzekało podróżników, szczególnie podróżników-malarzy. Było zupełnie inne niż to, które znali z Europy. Kolory wydawały się bardziej nasycone, intensywniejsze, prawdziwsze $^{8}$. Kiedy Eugène Delacroix przybył do Tangeru, zapisał, że słońce jest tam „najpiękniejsze na świecie" ${ }^{9}$. Słońcem Egiptu zachwycał się w swoich notatkach z podróży na Wschód bardzo czuły na piękno krajobrazu Gustave Flaubert. Kiedy dobijał do brzegów Aleksandrii, jego uwagę zwróciło właśnie niezwykłe światło: „Wdrapałem się na wanty i ujrzałem dach pałacu Muhammada Alego, którego kopuła błyszczała w słońcu na czarno pośród wielkiego blasku srebra rozpuszczającego się w morzu" ${ }^{\prime 10}$. Nic dziwnego więc, że Aline de Lens - malarka - również zauroczyła się tunezyjskim słońcem i światłem. Nie nastąpiło to jednak od razu. Opisane w dzienniku spotkanie $\mathrm{z}$ Tunezją przebiega niejako $\mathrm{w}$ trzech etapach. Podróżujące statkiem z Marsylii małżeństwo po raz pierwszy schodzi na afrykański ląd w Bizercie,

\footnotetext{
7 B. Westphal, La Géocritique. Réel, fiction, espace, Paris 2007, s. 17.

8 Zob. Ch. Peltre, L'atelier du voyage. Les peintres en Orient au XIX siècle, Paris 1995, s. 68-71.

9 E. Delacroix, Journal (1822-1857), t. 1, Paris 2009, s. 275.

10 G. Flaubert, Voyage en Orient, red. C. Gothot-Mersch, Paris 2008, s. 77.
} 
mieście usytuowanym około 60 kilometrów na północny-wschód od Tunisu. Jest już wieczór, para nie widzi więc słońca, ogląda jedynie odbywającą się właśnie w mieście paradę pochodni:

[M]uzyka wojskowa przeplatała w dziwny sposób marsze francuskie i marsze arabskie o rozpraszającym rytmie. Po raz pierwszy wtopiliśmy się $\mathrm{w}$ tłum tubylców i ledwie mogliśmy dojrzeć w mroku roślinność zupełnie odmienną od naszej [s. 178].

Ciemność nie pozwala $\mathrm{w}$ pełni dostrzec odmienności kraju. $\mathrm{W}$ opisie diarystka bardziej skupia się na wrażeniach słuchowych niż wzrokowych. Francuska i arabska muzyka przypominają, że od 1881 roku Tunezja jest protektoratem francuskim ${ }^{11}$. Aline de Lens nie pisze jednak o Francuzach, lecz o ludności miejscowej. Zwrot „wtopiliśmy się w tłum tubylców” sugeruje, że podróżniczka chce należeć do tunezyjskiej przestrzeni, że niecierpliwie czekała na to spotkanie.

Kolejnym portem jest już Tunis. Para schodzi na ląd o szóstej. Aline de Lens nie opisuje światła (być może niezbyt imponującego o tej godzinie), skupia się natomiast na pewnej dychotomii tunezyjskiej stolicy:

Francuskie miasto, całe obwieszone flagami na cześć pana Fallières'a [ówczesny Prezydent Republiki, odwiedzał właśnie Tunezję - dop. M.S.], wydało nam się niezwykle banalne, ale - gdy tylko przekroczyliśmy tę francuską bramę poczuliśmy się oczarowani. Arabskie miasto - jakże je już kocham! [s. 179]

Tunis to niejako dwa miasta: francuskie (usytuowane blisko portu) i arabskie. Podróżniczka przekracza symboliczną granicę wpływów francuskich i znajduje się w części arabskiej, gdzie Francuzów w ogóle nie ma. Dociera w ten sposób do serca Tunisu. Opis doskonale oddaje ruch, przemieszczanie się w głąb miasta, jakby w poszukiwaniu tajemnicy:

Wychodząc z placu, który cały mieni się kolorowymi owocami ze straganów, przechodzimy na ulicę Halfaouine. Najpierw widać suk, na którym sklepiki rzeźników przeplatają się ze stoiskami sprzedawców kwiatów [...]. Potem ulica rozszerza się i przechodzi w plac Halfanouine. To duży plac, obsadzony chyba morwami, na którym wciąż roi się od tubylców. Szczególnie około piątej mauryjskie kawiarnie dookoła placu są pełne, a czarni śpiewacy i muzycy grający na darbukach dziko hałasują [s. 179].

„Przestaje się być człowiekiem. Zaczyna się być okiem”, napisał Flaubert w liście do Louise Colet ${ }^{12}$. Choć do sformułowania tych zdań zainspirowała

11 Aline de Lens praktycznie nie pisze o tym w swoim dzienniku. Relacjonuje głównie kontakty z Tunezyjczykami, obecność rodaków jest pominięta. Zupełnie inaczej opisuje Maroko, w którym obecność Francuzów zdaje się być o wiele intensywniejsza i ważniejsza. 
go lektura Szekspira, potem często cytowano je, żeby nazwać bardzo plastyczny sposób, w jaki Flaubert konstruuje swoje opisy, również w notatkach z podróży ${ }^{13}$. Takim "okiem” staje się też Aline de Lens. Chociaż Ellen Amster klasyfikuje jej spojrzenie jako „Colonial Eye/I”, oko kolonialne i europocentryczne ${ }^{14}$, tunezyjska część dziennika nie stanowi jednak absolutnie manifestacji europejskiej wyższości nad autochtonami. Wprost przeciwnie, fascynacja kolorytem lokalnym zdaje się być szczera i wynika z odrzucenia Francji.

Po prawie półtora roku pobytu w Tunezji, Aline de Lens spędza dwa miesiące wakacji w swoim rodzinnym kraju. We wrześniu wraca do Tunisu i pisze: „mokre, zimne, szare dwa miesiące, [a teraz] odnaleźliśmy słońce, błękitne niebo, Arabów w pięknych jebbach [rodzaj długiej tuniki noszonej przez kobiety i mężczyzn - dop. M.S.]. Święto dla oczu [...]!" [s. 186]. To w Tunezji, a nie we Francji toczy się jej życie. To słoneczna Tunezja, a nie szara Francja staje się jej prawdziwą ojczyzną.

Francuzka zdaje się całkowicie odnajdować w nowym kraju, właśnie ze względu na jego piękno. Wieczorami, po kolacji, małżeństwo wychodzi na taras, siada w fotelach, "temperatura jest wyborna":

Dochodzi nas gwar z placu Halfaouine; dookoła rozciągają się olśniewająco białe tarasy. Gdzieniegdzie, spomiędzy murów wyłania się palma lub eukaliptus; pobliski meczet krągli się śnieżnymi kopułami, minarety wyciągają się ku niebu. Na zachodzie, na złotym tle zachodzącego słońca, wznoszą się pokryte lasem wzgórza Belwederu, na wschodzie, w dali, widać błękitne góry. Jeśli jeszcze trochę tu zostaniemy, usłyszymy muezzina zanoszącego swoje rozpaczliwe pieśni czterem stronom świata. Czyste, głębokie niebo rozświetla się gwiazdami. Ach, jakże cudowne jest życie! [s. 181]

Malarka czuje się szczęśliwa właśnie dzięki pięknej przestrzeni, która ją otacza. Tworzone przez nią opisy zachodów słońca przypominają czasem te, które wyszły spod pióra Flauberta ${ }^{15}$ :

12 G. Flaubert, Lettre à Louise Colet du 27 septembre 1846, w: tegoż, Correspondance. Tome I: Janvier 1830 - Juin 1851, red. J. Bruneau, Paris 1973, s. 364.

13 L. Czyba, L'CEil du peintre, w: Flaubert et la peinture, red. G. Séginger, Caen 2010, s. 24.

14 Cytując pracę Meydy Jeğemoğlu, Colonial Fantasies: Towards a Feminist Reading of Orientalism (Cambridge 2015), badaczka rozwija koncept „Colonial Eye/I”, który opiera się na homofonii angielskich słów „I" [ja] oraz "eye” [oko] i denuncjuje europocentryczne spojrzenie kolonizatora na podległy mu kraj. Zob. E. Amster, 'The Harem Revealed' and the Islamic-French Family: Aline de Lens and a French Woman's Orient in Lyautey's Morocco, „French Historical Studies" 2009, nr 3, s. 295.

15 Opisy Flauberta, szczególnie te z notatek z podróży na Wschód, pełne są kolorów, gry świateł. Czasem określa się je nawet mianem pre-impresjonistycznych. Zob. L. Czyba, L'CEil du peintre, s. 20. 
Na tarasie: cienie są uroczo blade i długie... Oświetlone mury przyjmują kolor rozgrzanej żółci, podobnej topionemu złotu. Potem staną się morelowe i różowe zanim zagaszą się $\mathrm{w}$ jasnym fiolecie i pokryją błękitem przezroczystych nocy, które zawsze zdają się być rozświetlone blaskiem księżyca.

Jaskółki znaczą na niebie szybkie ósemki, a ciężki lot gołębi nad tarasem sprawia, że przez chwilę pomarańczowe mury pstrzą się zielonymi, ulotnymi cieniami.

Świeży wietrzyk porusza morwy na placu Halfaouine; wydaje się, że cała natura odradza się i odpoczywa po przytłaczającym upale dnia [s. 181].

Tunezja to kraj tysiąca kolorów, gry świateł, detali, które sprawne oko malarki wychwytuje bez trudu. Niektóre z przedstawień wpisują się w estetykę impresjonizmu: chęć zatrzymania na chwilę ulotnych barw, unikatowego światła; przekonanie, że słońce nigdy nie zachodzi w identyczny sposób ${ }^{16}$ :

Dziś wieczorem na tarasie jedna $\mathrm{z}$ tych wybornych impresji zachodzącego słońca. Światła różowe, pomarańczowe, cienie bladozielone, niebieskie, jasnofioletowe, cała feeria barw, biel z tysiącem refleksów. André i ja patrzymy, jak zwykle zauroczeni widokiem, do którego nie można się przyzwyczaić i który pokazuje nieskończone bogactwo natury [s. 198].

Tym razem Aline de Lens nie opisuje widoku z tarasu dokładnie, wymienia tylko barwy, sugerując $w$ ten sposób niezwykłość spektaklu, który rozgrywa się przed jej oczami. Tunezyjskie światło i kolory zdają się zapewniać szczęście nieznane we Francji. To ziemski raj, absolutne piękno.

\section{Pustynia i oaza}

Orient fascynował podróżników, w tym malarzy, nie tylko ze względu na światło i kolor, ale też na pustynię. Flaubert widział w niej „[w]izerunek nieskończoności, gdzie nie da się żyć" ${ }^{17}$. Pustynia jako przestrzeń mistyczna, przestrzeń, która „obnaża duszę"18, powraca na kartach wielu relacji z podroży. Absolutnie oczarował się nią w Algierii pisarz i malarz Eugène Fromentin:

\footnotetext{
16 S.Z. Levine, Monet's Series: Repetition, Obsession, „October” 1986, nr 37, s. 72.

17 G. Flaubert, Słownik komunałów, przeł. J. Gondowicz, Kraków-Warszawa 1992, s. 100.

18 M. Viegnes, Vide et plénitude dans l'expérience du désert chez Fromentin, w: Le désert, un espace paradoxal. Actes du colloque de l'Université de Metz (13-15 septembre 2001), red. G. Nauroy, P. Halen, A. Spica, Bern 2003, s. 338.
} 
Równiny przechodzące $\mathrm{w}$ równiny: równiny jednolite, trzęsawiska, równiny piaszczyste, tereny suche i kamieniste, [...] ogrom złamanych linii, rozchodzących się we wszystkich kierunkach, [...] równina nieskończenie płaska, tak rozległa, że nie można jej objąć okiem i [ta] dziwna nazwa która daje do myślenia Bled-el-Ateuch, i jej tłumaczenie: Kraina pragnienia. - Inni cofnęliby się przed nagością podobnej wędrówki; ja jednak przyznam, że to właśnie ta nagość mnie pociąga $^{19}$.

Według Michela Brixa wygnany z Raju człowiek przez całe życie szuka drogi powrotnej. Stąd podróże, podczas których poszukuje miejsca idealnego, „świętego celu” ${ }^{20}$. Zdania te wydają się szczególnie prawdziwe w przypadku podróży wschodnich i wędrówki przez pustynię. W tym przypadku świętym celem często staje się oaza, metafora Raju, do którego droga wiedzie przez pustynną mękę życia.

Podczas pobytu w Tunezji Aline de Lens tylko raz wybiera się do oazy Tauzar, usytuowanej w środkowo-zachodniej części kraju. Oczywiście droga wiedzie przez pustynię:

[S]uniemy naprzód $\mathrm{w}$ pełnym słońcu. Rytm wyznaczają zwierzęta [muły dop. M.S.]. Samotność [wędrówki] sprawia, że ten płowy ogrom [przestrzeni] wydaje nam się jeszcze bardziej imponujący. Od czasu do czasu spotykamy karawanę, jeźdźców lub pieszych, z którymi wymieniamy powitania i błogosławieństwa. Czasem wzdłuż szlaku można dojrzeć rozproszone kości, szkielet wielbłąa lub muła, który zdechł w drodze. Poza tym, krajobraz pozostaje niezmienny, wydaje się, że podróżujemy w miejscu... W końcu pojawia się ciemna masa palm rosnących obok miasta, miasta płowego jak ziemia, $\mathrm{z}$ domami z cegły i błota, prymitywnymi i na wpół rozpadającymi się... [s. 193].

Opis przypomina słynny obraz Gustave'a Guillaumeta Sahara [Le Sahara] ${ }^{21}$ : na pierwszym planie leży częściowo odarty ze skóry szkielet wielbłąda, który zlewa się z piaskiem i niebem, doskonale oddając ten - jak go określiła Aline de Lens - „płowy ogrom” przestrzeni. „[W]szystko to, z jednego końca na drugi, jak daleko sięga wzrok nie jest ani czerwone, ani żółte, ani ciemnobrązowe, tylko dokładnie w kolorze skóry lwa" - tak opisywał tę barwę Fromentin ${ }^{22}$.

Pustynia u Aline de Lens zdaje się być przestrzenią opresyjną, z której trudno się wydobyć właśnie przez tę jednorodność krajobrazu. Co więcej,

\footnotetext{
19 E. Fromentin, Un été dans le Sahara, w: tegoż, Sahara et Sahel, Paris 2004, s. 7.

20 M. Brix, Nerval et le rêve égyptien, "Romantisme” 2003, nr 120, s. 38.

21 Zob. G. Guillaumet, Le Sahara, 1867, olej na płótnie, 110 x 200 cm, Musée d'Orsay, Paryż.

22 E. Fromentin, Un été dans le Sahara, s. 26.
} 
pustynia wdziera się też $\mathrm{w}$ oazę, która u pamiętnikarki nie jest jednoznacznie rajska. Widać to szczególnie $\mathrm{w}$ pierwszej relacji z pobytu $\mathrm{w}$ Tauzar, poprzedzającej opis drogi:

W oazie, pod wysokimi dumnymi palmami rośnie lasek drzew owocowych: morele, brzoskwinie, drzewka pomarańczy, granatu... Wiosną pokrywają się kwiatami, a latem uginają pod ciężarem owoców.

Ale kogo to interesuje! Są tam jedynie po to, żeby dawać cień, zapewniać wilgotne podłoże cennym [palmom daktylowym] [s. 191].

Z pewną naiwnością kobieta oburza się przeciwko nierównemu traktowaniu roślin. Tunezyjska oaza to przede wszystkim daktyle, które zapewnią ludziom dochód. Życie oazy podporządkowane jest zbiorom. Tymczasem malarka chce bronić piękna: drzew, ich kwiatów i owoców.

Mimo wszystko, jednak, opisy pozytywne dominują. W oazie Aline de Lens doświadcza zupełnie nowych doznań estetycznych. O świcie przechadza się tam wzdłuż rzeczek, które

radośnie przecinają delikatny piasek. Od czasu do czasu można spotkać tam kobiety piorące wełnę, wiecznie przykucnięte $\mathrm{w}$ wodzie [...]. Gdy przyjechaliśmy, gęste ogrody rosnące pod wysokimi palmami były całe różowe dzięki kwitnącym brzoskwiniom; gdy wyjeżdżaliśmy zaczęły, dzięki drzewkom granatu, przyjmować barwę szkarłatną. [Usytuowane] na środku pustyni miasto to jest zupełnie płowe. Domy, kozy, wielbłądy, Beduini też wydają się być jednakowo płowi [...] [s. 196].

W swoich opisach diarystka tworzy gotowe pejzaże, w których pojawiają się te same motywy. Tak, jakby Francuzka zapamiętywała wizytę w oazie właśnie poprzez powracające obrazy: gęsty las drzew owocowych obsadzonych pomiędzy palmami i „płowy ogrom” przestrzeni. W dzienniku rysuje się też wyraźna opozycja między rajską oazą i monotonną, opresyjną pustynią.

\section{Pałac, harem i hammam}

Pewne przestrzenie tworzą europejskie wyobrażenia na temat Lewantu. Należą do nich orientalny pałac, harem i hamman. Zdają się one odpowiadać orientalnym stereotypom dotyczącym bogactwa wschodniego świata, jego ornamentyki, ale i rozwiązłości. Harem i hammam od dawna pobudzały wyobraźnię Europejczyków, a francuski orientalizm w dużej mierze opierał się na przedstawieniach zmysłowych odalisek lub zalotnych kąpiących się kobiet $^{23}$.

23 Zob. J.-L. Tritter, Mythes de l'Orient en Occident, Paris 2012, s. 163-190. 
Opisy Aline de Lens częściowo wpisują się w ten sposób przedstawienia. Malarkę szczególnie zachwyca luksus tunezyjskich domostw. Sama zresztą mieszka w pałacu:

Nasze życie jeszcze jest dziwniejsze i bardziej jeszcze urocze, odkąd mieszkamy w tym cudnym pałacyku obłożonym białym marmurem i starymi, ręcznie malowanymi kaflami. [...] Z zewnątrz nic go nie wyróżnia: jak wszystkie domy arabskie, bogate i biedne, ma płaską, bardzo białą fasadę, prosto zdobioną zaokrąglonymi maszrabijjami. Jednakże wielkie, drewniane, rzeźbione drzwi zdradzają luksus wnętrz. Już od wejścia oczy zaczynają się radować na widok tych wszystkich polichromii, malowanych i złoconych sufitów, wielkich żyrandoli $\mathrm{z}$ weneckiego kryształu, rzeźbionych, marmurowych obramowań, harmonijnie kolorowych drzwi [s. 179].

Pisarka podkreśla przepych wschodniego świata. Opis pałacu współgra też z procesem poznawania Tunezji: fasada jedynie sugeruje luksus wnętrza, wejście do środka staje się metaforą odkrywania kraju. W centrum domu znajduje się patio $\mathrm{z}$ "fontanną z białego marmuru" [s. 179]. To zdaje się być serce pałacu, serce Tunezji.

Diarystka mebluje pałac na sposób arabski „meblami ze złoconego drewna pomalowanymi w ptaki i kwiaty [...], poduszkami, otomanami, taboretami do podawania kawy, skrzyniami etc." [s. 180]. Malarka chce żyć tak, jak Arabowie, całkowicie wniknąć w tunezyjską przestrzeń. Czasem wydaje się wręcz być przykładem transfuge culturel, kulturowego odstępcy, który, według definicji Jánosa Riesza, „zmienia swój status człowieka cywilizowanego na status człowieka "prymitywnego», «dzikiego» i odnajduje w tym szczęście" 24. Wybiera kulturę Innego, odrzucając swoją.

Dobrze widać to we fragmencie, w którym Aline de Lens opisuje wizytę $\mathrm{w}$ haremie. Wieczorem sąsiadki proszą, by za pomocą drabiny zeszła do nich ze swojego tarasu. Wizyta łączy się więc znów z przekroczeniem pewnej granicy, przeniknięciem „w głąb”. Później jednak, co ciekawe, malarka w ogóle nie skupia się na opisie przestrzeni. Nie przedstawia w żaden sposób wnętrza haremu, koncentruje się natomiast na zachowaniu kobiet. Harem jest przestrzenią szczególną, budowaną przez kobiety, miejscem tworzonym przez aktywność ludzką ${ }^{25}$.

24 J. Riesz, De la littérature coloniale à la littérature africaine. Prétextes - Contextes - Intertextes, Paris 2007, s. 51. Przymiotniki "cywilizowany”, "pierwotny”, "dziki” mają znaczenie umowne. Aline de Lens uważała Francję za „zbyt ucywilizowaną". Tunezyjczycy w jej dzienniku nigdy nie są określani jako lud „pierwotny” lub „dziki”. To po prostu inna cywilizacja, cywilizacja piękna.

25 Zob. B. Westphal, La Géocritique. Réel, fiction, espace, s. 16. 
Wizyta Francuzki jest dla Tunezyjek wielką atrakcją. Bardzo chcą pokazać sąsiadce to, co mają najpiękniejsze. Doświadczenie Tunezji znów staje doznaniem estetycznym:

Najpierw rozpakowujemy satynowe spodnie i staniki wyszywane złotem $\mathrm{w}$ olśniewających kolorach, prążkowane futy [typ spódnic - dop. M.S.], wstążki i koronki. Potem, pośród śmiechów i krzyków, zaczynają mnie ubierać [s. 182].

Harem przedstawiony w dzienniku Aline de Lens to nie bajkowe miejsce rozwiązłości, lecz przestrzeń kobiecych aktywności, smutków i radości. W dzienniku pisarka demitologizuje tę przestrzeń, ale jednocześnie jednoznacznie pokazuje, jak bardzo lubi w niej przebywać, zwłaszcza jako ta, którą Tunezyjki $\mathrm{w}$ pełni akceptują, jako jedna $\mathrm{z}$ nich.

Przestrzenie kobiece fascynują Francuzkę. Widać to szczególnie w przypadku hammamu, który odwiedza właśnie w Tunezji. Ekscytację wyczuwa się już we wprowadzeniu: diarystka pisze, że była na wielu tunezyjskich ślubach. Dodaje, że "zaczyn[a] być już znużona tą wzruszającą chwilą, w której małżonek odsuwa woal i po raz pierwszy ogląda swoją żonę" [s. 197]. Nigdy jednak nie była w łaźni. Kobiety udają się tam pod osłoną nocy w szczelnie zamkniętym powozie (żaden obcy mężczyzna nie może ujrzeć twarzy szanującej się muzułmanki). Wejście do łaźni poprzedza przebieralnia, "dość duża sala pomalowana krzykliwie na zielono i czerwono" [s. 197]. To tam kobiety rozbierają się i ubierają. Francuzka nie chce jednak zdjąć ubrania ${ }^{26}$. W gorącu łaźni wytrzymuje tylko dwie minuty. Wystarczy to jednak, żeby opisać „najdziwniejszy spektakl”:

przez gęstą mgłę [widać] wielką liczbę nagich kobiet: grube, szczupłe, niskie, wysokie, czarne, białe, stare, młode, krążą, gestykulują, plotkują. Pespektywa takiego widoku wzbudziłaby zapewne lubieżne myśli u większości panów chętnych czerpać przyjemności z tego typu rzeczy. Myślę jednak, że tak naprawdę byliby podobnie jak ja oszołomieni tym zbiorowiskiem kobiecych ciał, niewątpliwie groteskowym. Zapewne były tam kobiety ładne i kształtne, ale ginęły w okropnej masie pozbawionej jakiegokolwiek wdzięku. Niezwykła matrona bezwstydnie eksponowała swą tuszę, godną by ją obwozić po jarmarkach, obok szkieletowatych staruch, kompletnie wychudłych, podobnych do harpii.

Naprawdę był to spektakl iście piekielny [...] raczej niż wizja muzułmańskiego raju! [s. 197-198]

26 Tak samo jak autorka najbardziej znanego europejskiego opisu tureckiej łaźni lady Mary Wortley Montagu. Por. M. Wortley Montagu, April 1, [1717]. To the Lady---, w: tejże, Letters, London 1992, s. 105. 
Łaźnia traci swoje erotyczne konotacje. Przestrzeń ta przedstawiona jest zupełnie odmiennie od tej, którą opisywała lady Montagu, malował Ingres czy Gérôme. Wypełniona kobietami i tworzona przez kobiety staje się groteskowa. Aline Lens dekonstruuje kolejny mit dotyczący Wschodu i jego przestrzennych atrybutów.

\section{Podsumowanie}

Oczywiście na postrzeganie Tunezji przez Aline Réveillaud de Lens wpływa wiele czynników. Jedzie tam kobieta zakochana, która potrzebuje nowego miejsca z dala od Francji, aby pielęgnować swoją miłość. „Żyję w pałacu, w kraju, który kocham i którego światło, kolor, malowniczość spełniają moje marzenia. Nie mam nic innego do roboty jak tylko malować i kochać mojego [...] André" [s. 187], wyznaje. Jedzie tam malarka, która znajduje w Tunezji nieskończone inspiracje dla swoich prac. Zresztą malarskie oko zdradzają też tworzone przez nią opisy, skoncentrowane na zmieniającym się świetle, grze kolorów i przez to wyjątkowo plastyczne.

To wszystko sprawia, że tunezyjskie przestrzenie opisywane w jej dzienniku są przede wszystkim piękne. We wrześniu 1914 roku, już w Maroku, którego na początku zupełnie nie akceptuje, przerażona wojną malarka nagle przypomina sobie spacer po oazie Tauzar:

[Gospodarz] posadził nas na dywanach pośrodku swojego rajskiego ogrodu i zaoferował nam lagmi (wino palmowe) i pomarańcze. W segujach [kanały irygacyjne - dop. M.S.] krystalicznie dźwięczała woda, trawa była świeża, drzewa granatu tworzyły wielkie, pachnące bukiety. Nasz gospodarz nazrywał dla mnie mnóstwo tych kwiatów.

Potem, jako że byliśmy z dala od Tauzar, pożyczył mi konia [...]. I znów to mam przed oczami: spokojny stęp białego wierzchowca, [...] różowy wieczór zapadający nad pustynią, ścieżki oazy w cieniu wysokich palm i naręcze kwiatów, które spowijały mnie swoim zapachem [s. 233].

„Przestrzeń - i świat który uobecnia - są owocem symboliki, pewnej spekulacji [...] i wyobraźni", pisze Westphal ${ }^{27}$. W taki sposób Aline de Lens tworzy opisy przestrzeni w swoim dzienniku. Korzysta $\mathrm{z}$ istniejących przedstawień, przepuszczając je przez pryzmat swoich emocji i wyobrażeń. Stąd rajski obraz oazy, opresyjna płowość pustyni, przepych wschodniego pałacu. Diarystka nie boi się jednak wyjść poza stereotypowe przedstawienia. Tunezyjski harem

27 B. Westphal, La Géocritique. Réel, fiction, espace, s. 10. 
i hammam nie mają $\mathrm{w}$ sobie nic $\mathrm{z}$ erotycznej europejskiej fantazji wieku XIX. To przestrzeń kobieca, całkowicie odmitologizowana.

Francuzka podziwia, ale nie idealizuje. Jej fascynacja tunezyjską przestrzenią wydaje się naturalna, niewymuszona. Brak w niej też jakiejkolwiek europejskiej wyższości. Wprost przeciwnie, Aline Réveillaud de Lens Tunezje podziwia i w pełni akceptuje. Protektorat wcale nie jest protektoratem, staje się anty-Francją, rajem młodej zakochanej malarki.

\section{Bibliografia}

Amster Ellen (2009), 'The Harem Revealed' and the Islamic-French Family: Aline de Lens and a French Woman's Orient in Lyautey's Morocco, "French Historical Studies", nr 3 (32), s. 279-312.

Brix Michel (2003), Nerval et le rêve égyptien, „Romantisme”, nr 120, s. 37-46.

Czyba Luce (2010), L'CEil du peintre, w: Flaubert et la peinture, red. G. Séginger, Caen: Lettres Modernes Minard, s. 19-39.

Delacroix Eugène (2009), Journal (1822-1857), t. 1, Paris: José Corti.

Flaubert Gustave (1973), Correspondance. Tome I: Janvier 1830 - Juin 1851, red. J. Bruneau, Paris: Gallimard.

Flaubert Gustave (1992), Słownik komunałów, przeł. J. Gondowicz, Kraków-Warszawa: Fundacja „Brulionu”.

Flaubert Gustave (2008), Voyage en Orient, red. C. Gothot-Mersch, Paris: Gallimard. Fromentin Eugène (2004), Sahara et Sahel, Paris: Editions Paris-Méditerranée.

Lebel Roland (1931), Histoire de la littérature coloniale en France, Paris: Librairie Larose.

Lejeune Philippe (1993), Le moi des demoiselles: enquête sur le journal de jeune fille, Paris: Éditions du Seuil.

Lens de Aline Réveillaud (1925), L'étrange aventure d'Aguida, Paris: Les Éditions de France.

Lens de Aline Réveillaud (2007), Journal 1902-1924. „L'amour, je le supplie de m’épargner...", Paris: La Cause des Livres.

Levine Steven Z. (1986), Monet's Series: Repetition, Obsession, „October”, nr 37, s. 65-75.

Peltre Christine (1995), L'atelier du voyage. Les peintres en Orient au XIXe siècle, Paris: Gallimard.

Riesz János (2007), De la littérature coloniale à la littérature africaine. Prétextes - Contextes - Intertextes, Paris: Karthala.

Tritter Jean-Louis (2012), Mythes de l'Orient en Occident, Paris: Ellipses.

Viegnes Michel (2003) Vide et plénitude dans l'expérience du désert chez Fromentin, w: Le désert, un espace paradoxal. Actes du colloque de l'Université de Metz (13-15 septembre 2001), red. G. Nauroy, P. Halen, A. Spica, Bern: Peter Lang, s. 337-348. Westphal Bernard (2007), La Géocritique. Réel, fiction, espace, Paris: Les Editions de Minuit.

Wortley Montagu Mary (1992), Letters, London: Everyman's Library. 
Viegnes M. (2003), Vide et plénitude dans l'expérience du désert chez Fromentin, w: Le désert, un espace paradoxal. Actes du colloque de l'Université de Metz (13-15 septembre 2001), red. G. Nauroy, P. Halen, A. Spica, Bern.

\title{
"Ah, Life is Wonderful!": Tunisian Fascinations by Aline Réveillaud de Lens (Space)
}

\begin{abstract}
The present paper concentrates on the descriptions of Tunisia in the diary by Aline Réveillaud de Lens (1881-1925), a French painter and writer who in 1911, shortly after her marriage, came to live in Tunis. Reluctant to French norms and conventions, de Lens sees Tunisia as an ideal, fascinating land where she may finally be happy. This fascination is reflected in her descriptions of spaces which are to be analysed through the prism of geocriticism in three movements: Tunisia as a land of light and colours, Tunisian symbolic spaces - desert and oasis, and stereotypical Oriental spaces - palace, harem and hammam.
\end{abstract}

Keywords: diary, Tunisia, space, 20th-century travel literature 